\title{
The Video Head Impulse Test in a Case of Suspected Bilateral Loss of Vestibular Function
}

\author{
Pedro L. Mangabeira Albernaz ${ }^{1} \quad$ Flavia Salvaterra Cusin ${ }^{2}$ \\ ${ }^{1}$ Department of Otolaryngology, Hospital Albert Einstein, São Paulo, \\ SP, Brazil \\ ${ }^{2}$ Department of Audiology and Speech Pathology, Hospital Israelita \\ Albert Einstein, Sao Paulo, SP, Brazil \\ Address for correspondence Pedro L. Mangabeira Albernaz, MD, PhD, \\ Department of Otolaryngology, Hospital Albert Einstein, Av. Albert \\ Einstein, 627 Sala 117, São Paulo, SP 05652-000, Brazil \\ (e-mail: plmalbernaz@uol.com.br).
}

Int Arch Otorhinolaryngol 2016;20:84-86.

\begin{abstract}
Introduction A patient who had no symptoms suggestive of bilateral loss of vestibular function presented no responses in rotational and caloric tests.

Objectives To demonstrate the importance of the video head impulse test in neurootologic diagnosis.

Keywords

Resumed Report This patient had a neuro-otologic evaluation and presented no

- vestibular diseases

- vestibular function tests

- head impulse test responses in torsion swing tests, caloric tests, and rotational tests in a Bárány chair. The video head impulse test elicited responses in four of the six semicircular canals. Conclusion Absent responses in caloric and rotatory tests alone are not sufficient to diagnose bilateral loss of vestibular function.
\end{abstract}

\section{Introduction}

Bilateral loss of vestibular function is a severely incapacitating labyrinthine disorder, causing disequilibrium and oscillopsia. It can result from cranial trauma, infectious diseases (particularly meningitis), degenerative central nervous system syndromes, toxic and autoimmune inner ear disorders, and cochlear implants. ${ }^{1}$

Bilateral loss of vestibular function is often diagnosed by the absence of responses with ice-cold caloric stimulations, ${ }^{2}$ but rotational stimulation has been suggested as an added support for this diagnosis. ${ }^{3}$ The head impulse test was described by Halmagyi and Curthoys in $1988 .{ }^{4}$ They stated that quick head movements induce saccadic eye movements and demonstrated that these saccades resulted from the stimulation of phasic receptor cells in the crista of one of the lateral semicircular canals, the contralateral one being inhibited by the quick movement, of the order of 200 degrees per second. These physiologic principles have been confirmed by other investigators. ${ }^{5}$

Aw et al, ${ }^{6-8}$ Cremer et al, ${ }^{9}$ and Halmagyi et $\mathrm{al}^{10}$ verified that with the patient's head in different positions it was possible to investigate each of the six semicircular canals. Magnuson et al demonstrated ${ }^{11}$ that it was possible to improve the reliability and sensitivity of the test using videonystagmoscopy. The video head impulse test (vHIT) is easier to interpret, particularly in relation to the vertical canals.

The vestibular system operates at frequencies from 0 to $16 \mathrm{~Hz}$, mainly in the area of 0.1 to $10 \mathrm{~Hz}$. Caloric tests stimulate frequencies from 0.03 to $0.06 \mathrm{~Hz}$; rotation tests provide stimuli from 0.01 to $0.5 \mathrm{~Hz}$. vHITs explore the frequencies in the range of 2 to $10 \mathrm{~Hz}$ and therefore stimulate an area of important activity of the system. ${ }^{12}$ In addition to the frequencies involved, the vHIT allows evaluation of all six semicircular canals.

This study describes the case of a patient in whom the vHIT test was important in establishing the diagnosis.

\section{Case Report}

The patient was a white woman born October 8, 1973. She was seen in consultation on May 5, 2014, with a complaint of hearing loss and sensation of pressure in the left ear immediately after having a colonoscopy, during which she was given mannitol. Two days later, she had an intense manifestation of allergic rhinitis. She also complained that after the colonoscopy her vision was cloudy when she awoke each morning. received

October 14, 2014

accepted

October 18, 2014

published online

December 10, 2014
DOI http://dx.doi.org/

10.1055/s-0034-1395999. ISSN 1809-9777.
Copyright $\odot 2016$ by Thieme Publicações License terms Ltda, Rio de Janeiro, Brazil

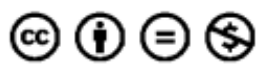


When she was 10 years old, she noticed that she had no hearing on the right ear. She also mentioned that she suffered from asthma until age 12 but nowadays has only an allergic rhinitis. In 1973 she had computerized tomography scans of the temporal bones; the scans were normal.

Her ear, nose, and throat examination was found to be essentially normal. The Romberg test showed a light tendency of deviation to the left side. The cerebellar tests were normal. The subjective vertical test showed a 2-degree deviation to the left side. Spontaneous and gaze nystagmus with the eyes open were absent. A neuro-otologic examination was performed on June 2, 2014.

The audiological tests revealed profound hearing loss on the right ear and essentially normal hearing on the left, with normal speech discrimination. - Fig. 1 shows the patient's audiogram.

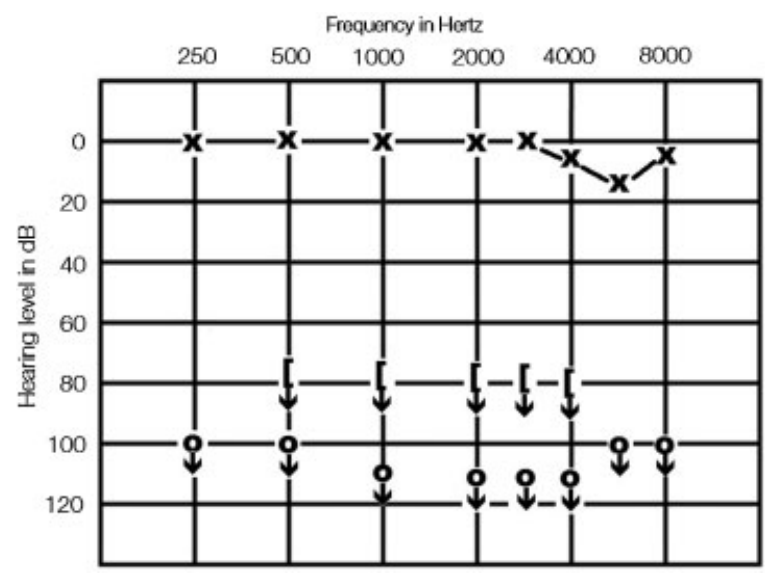

Fig. 1 Patient's pure tone audiogram.
The conventional vestibular examination, performed with vector nystagmography recording, showed the following results:

- spontaneous and gaze nystagmus: absent

- pendular eye tracking: type I (normal)

- optokinetic nystagmus: normal and symmetrical

- torsion swing tests: no responses

- caloric tests: no responses

- constant acceleration rotatory tests (Bárány): no responses obtained for any of the semicircular canals

These findings are suggestive of a bilateral loss of vestibular function, as no responses were obtained either with rotational or caloric tests.

The patient then had a vHIT using an Otometrics ICS Impulse system (GN Otometrics, Denmark). - Figs. 2 and $\mathbf{3}$ show the results. The test revealed vestibular responses, with reduced vestibulo-ocular reflexes (VOR) for the lateral canals and for the left posterior and right anterior semicircular canals. The left anterior and right posterior semicircular canals showed no reflexes.

Because vHIT stimulates the six vestibular semicircular canals at frequencies higher than those of the rotational and caloric tests, it was surmised that her vestibular disorder was more intensely related to low-frequency responses and that, despite her smaller than normal VOR reflexes, she did not have a bilateral loss of vestibular function.

In view of the patient's reaction to mannitol and the symptom of cloudy vision in the morning, a glucose tolerance test with simultaneous insulin titration was ordered. She was found to have low insulin values. - Table 1 shows the glucose and insulin levels. A lactose tolerance test was ordered, and
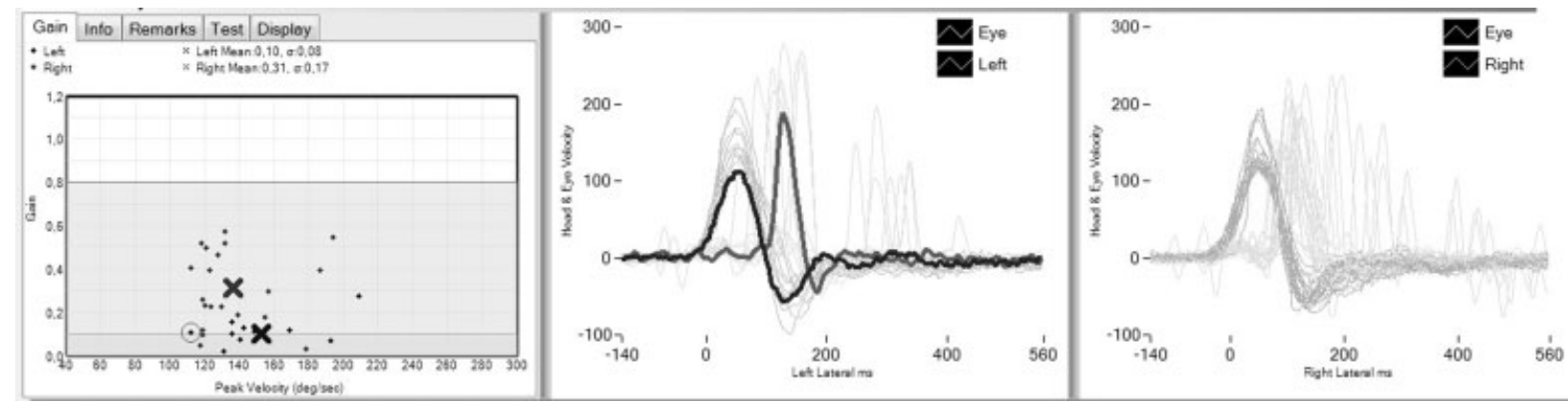

Fig. 2 Vestibulo-ocular reflexes of the lateral semicircular canals.
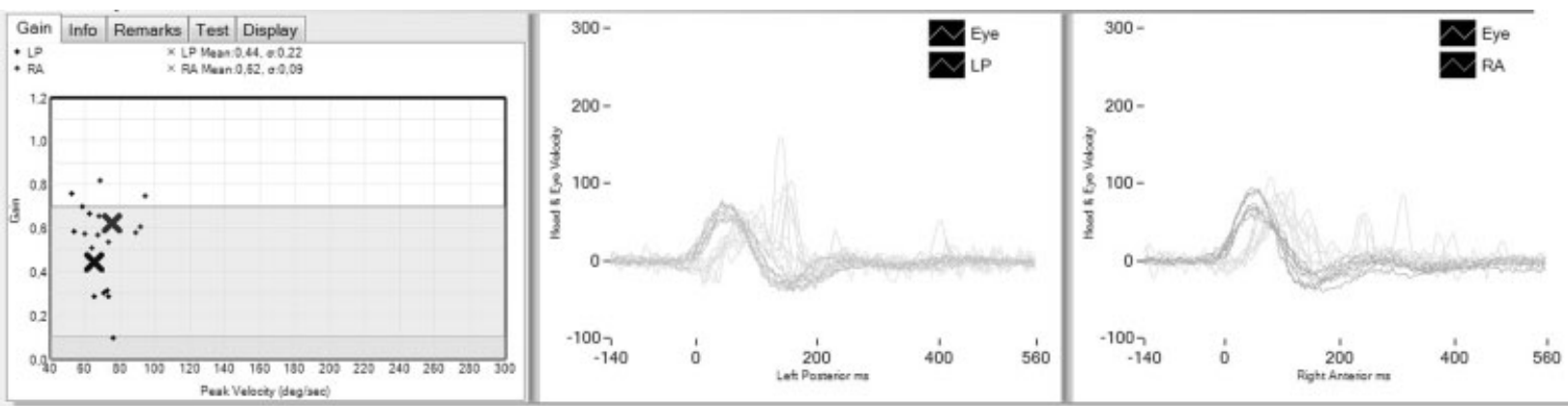

Fig. 3 Vestibulo-ocular reflexes of the left posterior and right anterior semicircular canals. 
Table 1 Glucose and insulin blood levels

\begin{tabular}{|l|l|l|l|l|l|l|}
\hline & \multicolumn{6}{|l|}{ Time (min) } \\
\cline { 2 - 7 } & $\mathbf{0}$ & $\mathbf{3 0}$ & $\mathbf{6 0}$ & $\mathbf{9 0}$ & $\mathbf{1 2 0}$ & $\mathbf{1 8 0}$ \\
\hline Glucose $(\mathrm{mg} / \mathrm{dL})$ & 83 & 121 & 109 & 90 & 69 & 68 \\
\hline Insulin $(\mu \mathrm{lU} / \mathrm{mL})$ & 3 & 17 & 25 & 24 & 14 & 6 \\
\hline
\end{tabular}

Table 2 Glucose values after lactose intake

\begin{tabular}{|l|l|l|l|l|}
\hline \multirow{2}{*}{} & \multicolumn{4}{|l|}{ Time (min) } \\
\cline { 2 - 5 } & 0 & 30 & 60 & 90 \\
\hline Glucose $(\mathrm{mg} / \mathrm{dL})$ & 83 & 83 & 86 & 91 \\
\hline
\end{tabular}

the patient was found to have a brush border membrane disease, characterizing lactose intolerance. ${ }^{13}$ - Table 2 shows the glucose blood levels after the ingestion of $50 \mathrm{~g}$ of lactose.

It was concluded that the disturbance caused by the administration of mannitol during the colonoscopy was the cause of the changes in carbohydrate metabolism that determined the patient symptoms. It must be taken into consideration, however, that the patient had a previous inner ear disorder, probably of viral origin, that occurred during her childhood. The patient is now on a diet for brush border membrane disease and is stable.

\section{Discussion}

It was particularly interesting to note that the vestibular tests characterized a bilateral loss of vestibular function. Bilateral loss of vestibular function, however, is a severely incapacitating disorder that causes intense disequilibrium and, in most cases, oscillopsia. ${ }^{1}$ This patient relates occasional episodes of unsteadiness, but she leads an active life, walks normally, and drives her car without problems.

On the other hand, the vHIT tests show that she has residual high-frequency vestibular function in four of the six semicircular canals, a finding that agrees with the patient's balance condition.

\section{Conclusion}

The findings in this case led to the conclusion that absent responses in caloric and rotatory tests alone are not suffi- cient to diagnose bilateral loss of vestibular function. Because vHIT evaluates the six semicircular canals, it should be considered essential in the evaluation of vestibular function absence.

\section{References}

1 Mangabeira-Albernaz PL. Arreflexia Vestibular Bilateral. In: Zuma e Maia FC, Mangabeira-Albernaz PL, Carmona S, eds. Otoneurologia Atual. Rio de Janeiro, Brazil: Revinter; 2014: 399-403

2 Bittar RSM, Bottino MA, Pedalini MEB, et al. Arreflexia calórica bilateral: aplicabilidade clínica da reabilitação vestibular. Rev Bras Otorrinolaringol 2004;70(2):188-193

3 Ulmer E, Magnan J, Chays A. Aréflexie vestibulaire bilatérale: une notion toute relative. Ann Otolaryngol Chir Cervicofac 2002; 119(4):216-226

4 Halmagyi GM, Curthoys IS. A clinical sign of canal paresis. Arch Neurol 1988;45(7):737-739

5 Wuyts F. Principle of the head impulse (thrust) test or Halmagyi thrust test. B-ENT 2008;4(Suppl 8):23-25

6 Aw ST, Haslwanter T, Halmagyi GM, Curthoys IS, Yavor RA, Todd MJ. Three-dimensional vector analysis of the human vestibuloocular reflex in response to high-acceleration head rotations. I. Responses in normal subjects. J Neurophysiol 1996;76(6): 4009-4020

7 Aw ST, Halmagyi GM, Haslwanter T, Curthoys IS, Yavor RA, Todd MJ. Three-dimensional vector analysis of the human vestibuloocular reflex in response to high-acceleration head rotations. II. Responses in subjects with unilateral vestibular loss and selective semicircular canal occlusion. J Neurophysiol 1996;76(6): 4021-4030

8 Aw ST, Halmagyi GM, Black RA, Curthoys IS, Yavor RA, Todd MJ. Head impulses reveal loss of individual semicircular canal function. J Vestib Res 1999;9(3):173-180

9 Cremer PD, Halmagyi GM, Aw ST, et al. Semicircular canal plane head impulses detect absent function of individual semicircular canals. Brain 1998;121(Pt 4):699-716

10 Halmagyi GM, Aw ST, Cremer PD, et al. Impulsive testing of individual semicircular canals function. Ann N TY Acad Sci 2001; 942:192-200

11 Magnuson M, Karlberg K, Halmagyi , et al. The video-impulse test enhances the possibility of detecting vestibular lesions. J Vestib Res 2002;11:241-244

12 Curthoys IS. The interpretation of clinical tests of peripheral vestibular function. Laryngoscope 2012;122(6): 1342-1352

13 Mangabeira-Albernaz PL, Miszputen SJ. Vertigem e Enzimas Digestivas. In: Zuma e Maia FC, Mangabeira-Albernaz PL, Carmona S, eds. Otoneurologia Atual. Rio de Janeiro, Brazil: Revinter; 2014: 365-379 